\title{
DZIAŁALNOŚĆ KATEDR HISTORII KOŚCIOLA STAROŻYTNEGO W POLSCE
}

W Polsce działają aktualnie dwie katedry historii Kościoła starożytnego w KUL i ATK; na każdej z nich blisko 50 lat prowadzone są zajęcia dydaktyczne i pisane prace dyplomowe $\mathrm{z}$ dziedziny starożytności chrześcijańskiej.

\section{KATEDRA HISTORII KOŚCIOŁA W STAROŻYTNOŚCI W KUL}

Katedra Historii Kościoła w Starożytności działa w ramach Instytutu Historii Kościoła, który dekretem Kongregacji Seminariów i Uniwersytetów z 6 II 1964 r. został utworzony na KUL-u. Od roku akademickiego 1965/66 kierownikiem Katedry był ks. prof. dr hab. Bolesław Kumor. W ciągu 16 letniej opieki nad Katedrą prowadził wykłady traktujące m.in. o Kościele w chrześcijańskim cesarstwie rzymskim, o genezie i rozwoju obrazoburstwa, o ustroju patriarchalnym przed Soborem Nicejskim, o patriarchacie ekumenicznym w Konstantynopolu i jego organizacji od IV do VIII wieku. W latach 1970-72 asystentem przy Katedrze był ks. mgr Anzelm Weiss. Od 1981 r. Katedrą kieruje ks. bp. prof. dr hab. Jan Śrutwa, a w 1993 r. asystentem został ks. dr Stanisław Koczwara.

1. Wykłady. Wykłady w całym Instytucie prowadzone są w zasadzie metodą monograficzną. Wyjątek stanowią wykłady z archeologii chrześcijańskiej ${ }^{1}$ i kursoryczny $z$ historii starożytnego Kościoła w Wyższym Seminarium Duchownym w Lublinie, będącym jednocześnie kursem zwyczajnym A na Wydziale Teologicznym KUL. Tematyka wykładów zwłaszcza w ostatnich latach dotyczyła głównie wzajemnych relacji pomiędzy Bizancjum i papieskim Rzymem na tle sytuacji społeczno-politycznej obszarów basenu Morza Śródziemnego.

${ }^{1}$ Do roku 1995 wykład ten prowadził ks. bp. Jan Śrutwa, potem przejął te zajęcia ks. Stanisław Koczwara po uzyskaniu licencjatu w Pontificio Istituto di Archeologia Cristiana w Rzymie na podstawie pracy zatytułowanej: Rito slavo sulle terre polacche alla luce della letteratura polacca di ricerca del $X X$ secolo pisanej pod kierunkiem prof. Mons. Patrick Saint-Roch. 
2. Prace dyplomowe i tematyka badań. Spośród kilkunastu prac magisterskich i licencjackich, znakomita większość dotyczyła spraw Kościoła w Afryce łacińskiej ${ }^{2}$. Dla uwagi przytoczę jedną z nich zatytułowaną: Papież Leon Wielki jako obrońca Rzymu w świetle świadectw historiograficznych do końca VIII wieku, napisaną przez ks. Jarosława Marczewskiego. Pracę tę warto odnotować nie tylko dlatego, że została wyróżniona nagrodą ministra Edukacji Narodowej, jako najlepsza praca magisterska z zakresu historii w 1995 roku, ale również dlatego, iż koncentrując swoją treść na słynnym spotkaniu papieża z wodzem Hunów - Atyllą, może stanowić lekcję dla obecnych przywódców politycznych, którzy powinni nauczyć się od Atylli, jak traktować wezwania do pokoju Jana Pawła II - sukcesora Leona Wielkiego także w dziedzinie obrony cywilizacji naprawdę ludzkiej ${ }^{3}$.

Jeśli weszliśmy już w świat historii pojmowanej jako nauczycielki życia, to na tle współczesnych zabiegów unijnych Europy, praca doktorska ks. Eugeniusza Derdziuka, traktująca o działalności mnichów iroszkockich w Europie, wskazuje, że przy budowie wspólnego domu, nie sposób pominąć chrześcijańskich zasad wypracowanych przez Kościół, który jawi się jako „niezastąpiony protagonista konsekwentnej humanizacji człowieczego bytowania na ziemi"

Tematyka kilku rozpraw doktorskich dotyczyła, podobnie jak wykłady, wzajemnych relacji między Kościołem wschodnim i zachodnim w V i VI wieku. Wymieńmy tu pracę ks. Feliksa Kowala o papieżu Gelazym i jego działalności na tle istniejącego rozłamu w Kościele, spowodowanego wystąpieniem patriarchy Konstantynopola - Akacjusza. Opisem przebiegu i procesem likwidacji schizmy akacjańskiej w oparciu o słynną formułę papieża Hormizdasa zajął się ks. Stanisław Koczwara. Z kolei ks. Dariusz Majewski podjął niezwykle ciekawy problem dotyczący działalności papieża Wigiliusza w Konstantyno-

${ }^{2}$ Por. ks. E. Derdziuk, Postawa chrześcijan-męczenników przed sądami pogańskimi w Afryce rzymskiej, 1982; ks. E. Boryca, Życie i działalność biskupów na podstawie synodów afrykańskich epoki przedaugustyńskiej, 1982; ks. L. Wira, Postawa duchowieństwa afrykańskiego wobec prześladowań w pot. III wieku, 1982; A. Firosz, Organizacja katechezy w Afryce tacińskiej w epoce św. Augustyna, 1983; ks. W. Szlachetka, Święty Marcelin (+413) - afrykański męczennik sprawy jedności Kościoła, 1987; ks. Wiesław Galant, Kwestia ważności chrztu heretyków w świetle synodu kartagińskiego z 256 roku, Lublin 1988. Pozostałe prace magisterskie dotyczą innych spraw, jak: ks. F. Kowal, Problemy ascezy wczesnochrześcijańskiej w ujęciu synodu w Gangra (z pot. IV w.), 1984; ks. Z. Skwierczyński, Problematyka rodziny i narodu w ujęciu synodów hiszpańsko-wizygockich VI-VII wieku, 1984; A. Kołodyńska, Chrystianizacja obyczajów w kazaniach św. Cezarego z Arles, 1985.

${ }^{3}$ Podobną lekcję posłuszeństwa wezwaniom biskupa Kościoła katolickiego można znaleźć w pracy magisterskiej ks. K. Grzesiaka pt. Pokuta kościelna cesarza Teodozjusza Wielkiego przebieg wydarzeń i echa w piśmiennictwie starożytnym, 1995.

${ }^{4}$ Ks. bp. J. Śrutwa, Katedra Historii Kościoła w Starożytności KUL, VoxP 9(1989) z. 16, s. 376; ks. E. Derdziuk, Metoda ewangelizacyjna mnichów iroszkockich na przykładzie św. Kolumbana Mtodszego (+615), Lublin 1995. 
polu w latach 547-555, wykazując, jak krzywdzące były opinie na temat działalności tego papieża nad Bosforem często spotykane w historiografii. Myśl tę podkreślił również ks. prof. dr hab. Emil Stanula z ATK w swojej recenzji $\mathrm{z}$ grudnia $1998 \mathrm{roku}^{5}$.

W trakcie realizacji są prace dotyczące podróży papieskich, zwłaszcza na Wschód, w I tysiącleciu, podejmowane nieraz w dramatycznej otoczce wydarzeń. Jądrem tych podróży papieskich była obrona nieskażonej wiary. Jest to o tyle ważne, że mimo licznych napięć, niepodzielny w gruncie rzeczy Kościół I tysiąclecia stanowić może jakiś wzorzec, wokół którego mogą koncentrować się wielorakie próby zjednoczeniowe zwłaszcza - jak byśmy powiedzieli językiem starożytnych pisarzy - wschodniej i zachodniej Szaty Chrystusa. Wszystkie te prace stanowią pewną próbę odpowiedzi na wezwanie Jana Pawła II, by taką ideę, na wzór starożytnych formuł zjednoczeniowych, poddać pod rozwagę podzielonym chrześcijanom na progu III tysiąclecia.

Inna problematyka badawcza, aczkolwiek różna od poprzednio wspomnianej, to przecież w jakiś sposób zazębiająca się o nią, ogniskowała się wokół sprawy niezwykle ciekawej, dotyczącej sposobu wyboru biskupów Rzymu w starożytności. Badania prowadzone przez ks. Wiesława Galanta obejmowały pierwsze cztery wieki Kościoła i uwieńczone zostały doktoratem 6 . Jakimś dopełnieniem tych badań, dającym pełny obraz zagadnienia, jest praca ks. Marka Sobieszka odnośnie elekcji papieskich w V wieku ${ }^{7}$. Na zakończenie tego punktu trzeba wspomnieć jeszcze o badaniach prowadzonych przez ks. Jerzego Czerwienia, dotyczących reperkusji uchwał Soboru Konstantynopolskiego z 381 r. w zachodniej części chrześcijańskiego cesarstwa.

3. Badania naukowe kierownika Katedry. Publikacje i naukowe zainteresowania ks. bpa Śrutwy dotyczą głównie treści społecznych zawartych w nauczaniu i praktyce kościelnej. Życie codzienne, teologia katolicka, relacje między Kościołem i państwem w starożytności, czyli to, co zazwyczaj określamy mianem sacrum i profanum, mają pokazać Kościół Chrystusowy w jego niezastąpionej roli zaszczepiania przez wieki ewangelicznego posłania dla dobra poszczególnego człowieka i ku pożytkowi społeczeństwa i państwa. Spośród licznych prac traktujących o tym, wyliczyć należy rzecz dotyczącą pracy w starożytnym chrześcijaństwie afrykańskim, pracę ukazującą stosunek chrześcijaństwa do publicznego życia w cesarstwie rzymskim III-IV wieku, czy wreszcie jedną z ostatnich dysertacji dotyczącą zaleceń pastoralnych św. Augustyna

${ }^{5}$ Por. ks. F. Kowal, Problematyka schizmy akacjańskiej $w$ działalności papieża Gelazego, 1994; ks. St. Koczwara, Dzieje schizmy akacjańskiej, 1993; ks. D. Majewski, Działalnośc papieża Wigiliusza w Konstantynopolu $w$ latach 547-555, 1998.

${ }^{6}$ Por. ks. W. Galant, Elekcje biskupów Rzymu do końca IV wieku, Lublin 1999.

${ }^{7}$ Ks. Sobieszek podjął już ten temat w pracy licencjackiej pt. Spór wokót elekcji papieża Bonifacego I - przebieg i konsekwencje, 1989. 
wobec najazdu Wandalów na Afrykę rzymską ${ }^{8}$. Wszystkie te prace należą do gatunku historiografii kościelnej, która odnosi się do owego potężnego wsparcia przez Kościół wszystkich tych sił społecznych i politycznych, które przyczyniają się do coraz bardziej ludzkiego bytowania człowieka.

Ks. Stanisław Koczwara

\section{THE ANCIENT CATHOLIC CHURCH HISTORY CHAIR AT THE CATHOLIC UNIVERSITY OF LUBLIN}

(Summary)

The presented activity of the Ancient Catholic Church History Chair describes its 35 (thirty five) years history of scientific researches the most important published books, didactic classes and finally subjects which are in the progress of researches now.

\section{KATEDRA HISTORII KOŚCIOŁA STAROŻYTNEGO W ATK}

1. Powstawanie i skład osobowy Katedry. W 1954 r. wraz z powstaniem Akademii Teologii Katolickiej utworzono dwie katedry historii Kościoła: Katedrę Historii Kościoła w Polsce i Katedrę Historii Kościoła Powszechnego. W 1967 r. z myślą o utworzeniu w przyszłości katedry historii Kościoła starożytnego został powołany na stanowisko starszego asystenta przy Katedrze Historii Kościoła w Polsce, którą kierował wówczas ks. prof. dr hab. Hieronim Eugeniusz Wyczawski, ks. mgr Andrzej Guryn, który jednak w 1972 r. zakończył pracę w Akademii ${ }^{9}$.

Ostatecznie Katedrę Historii Kościoła Starożytnego w ATK utworzono w 1983 roku. Dokonano wówczas reorganizacji wszystkich katedr w ramach specjalności historii Kościoła, a także powołano kuratora w osobie ks. prof. dr

${ }^{8}$ Z licznych prac ks. bpa Śrutwy wymieńmy kilka ostatnich: Św. Winfryd-Bonifacy Discipulus Romanae Ecclesiae, RTK 47(1995) z. 4, 265-274; Rozłam między chrześcijańskim Wschodem $i$ Zachodem oraz próby jego przezwyciężenia $w$ starożytności i średniowieczu, w: Unia brzeska w perspektywie czterech stuleci, Lublin 1998, 15-25; Najstarszy tacinski dokument kościelny, RTK 46(1999) z. 4, 281-290. Te i kilka wcześniejszych zostały ostatnio wydane razem pt. Studia z dziejów Kościoła w starożytności, Lublin 1999, RWKUL ss. 240.

${ }^{9}$ Por. H.E. Wyczawski, Historia Kościoła, w: XX lat Akademii Teologii Katolickiej. Księga Pamiątkowa 1954-1974, Warszawa 1976, 128-130. 
hab. Hieronima Eugeniusza Wyczawskiego. Pierwszym kierownikiem (p.o.) powstałej wówczas Katedry Historii Kościoła Starożytnego został ks. doc. dr hab. Franciszek Stopniak, który pracował wówczas na etacie docenta przy Katedrze Historii Czasów Nowożytnych i Współczesnych Kościoła. Od 1986 r. obowiązki kierownika Katedry pełnił ks. doc. dr hab. Wincenty Myszor, kierując jednocześnie w ramach specjalności patrologii Katedrą Historii Literatury i Teologii Starożytnego Wschodu.

W 1987 r. z części dotychczasowego Wydziału Teologicznego ATK utworzono Wydział Kościelnych Nauk Historycznych i Społecznych. W struktury tego Wydziału w ramy jego kierunku historycznego weszła również historia Kościoła. Przeniesiono wówczas struktury organizacyjne powstałe na Wydziale Teologicznym, w tym Katedrę Historii Kościoła Starożytnego. Kierownikiem (p.o.) tej katedry pozostał nadal ks. prof. dr hab. Wincenty Myszor. W 1992 roku po uzyskaniu stopnia naukowego doktora habilitowanego stanowisko kierownika katedry objął ks. dr hab. Jan Gliściński, do tego czasu adiunkt przy Katedrze Historii Literatury i Teologii Starożytnego Zachodu. Kierował on katedrą do 1996 roku, kiedy to zrezygnował z pracy w ATK. Stąd od 1996 r. stanowisko kierownika Katedry objął ponownie ks. prof. dr hab. Wincenty Myszor, który w roku następnym został także kuratorem całej specjalności historii Kościoła.

Od 1988 roku przy Katedrze tej pracuje ks. Tadeusz Kołosowski, najpierw przez rok na stanowisku asystenta stażysty, od 1989 roku na stanowisku asystenta, a od 1992 r. po uzyskaniu stopnia naukowego doktora na stanowisku adiunkta, które zajmuje do dnia dzisiejszego.

2. Zajęcia dydaktyczne. Na Wydziale Teologicznym ATK w 1965 r. dokonano istotnych przeobrażeń w programie studiów specjalności historii Kościoła. Przedłużono wówczas okres studiów z dwóch do czterech lat, a także rygorozum ex universa theologia zastąpiono rygorozum ex universa historia ecclesiastica $\mathrm{z}$ dodaniem tez $\mathrm{z}$ historii dogmatów i historii sztuki kościelnej. W programie studiów znalazło się wówczas miejsce na historię starożytną Kościoła, którą wykładano na pierwszym i drugim roku studiów w wymiarze dwóch godzin tygodniowo. Podczas pierwszego roku wykład obejmował dzieje Kościoła od początku jego powstania do przełomu konstantyńskiego, a w drugim dzieje Kościoła od Konstantyna Wielkiego do końca VII wieku. W wykładach tych uczestniczyli oprócz studentów historii Kościoła, studenci patrologii i archeologii chrześcijańskiej. Do 1967 r. wykłady te prowadził ks. prof. dr hab. Marian Michalski ${ }^{10}$, kierownik Katedry Patrologii ${ }^{11}$. Po

${ }^{10}$ Por. tamże, s. 132-133.

11 Por. E. Stanula, Patrologia, w: XX lat Akademii Teologii Katolickiej. Księga Pamiątkowa 1954-1974, Warszawa 1976, 149. 
nim w latach 1967-1971 historię starożytną Kościoła w ramach zajęć zleconych wykładał ks. dr Gustaw Klapuch, wykładowca historii Kościoła w katowickim seminarium duchownym. Z kolei przez rok akademicki 1971/72 czynił to ks. mgr Andrzej Guryn. Po jego odejściu z ATK przez kolejne dwa lata wykłady te prowadził ks. dr hab. Marian Banaszak. Od 1974 r. powyższe wykłady przejął ks. dr Wincenty Myszor, który od 1969 r. był asystentem, a od 1973 r. adiunktem przy Katedrze Patrologii ${ }^{12}$. Prowadził je do 1987 r., czyli do czasu przejścia historii Kościoła na nowo utworzony wówczas Wydział Kościelnych Nauk Historycznych i Społecznych.

Cechą charakterystyczną studiów na specjalności historii Kościoła był początkowo zupełny brak ćwiczeń. Jedynie w 1978/79 ks. doc. Franciszek Stopniak prowadził ćwiczenia z najnowszej historii Kościoła (1 godz. przez semestr), a od 1983/84 ks. dr Tadeusz Krahel. Brak ćwiczeń we właściwym wymiarze uzasadniał wówczas brak odpowiedniej liczby asystentów i adiunktów, a także obciążenie studentów znaczną liczbą zajęć z teologii ogólnej. Z zakresu historii Kościoła starożytnego ćwiczenia prowadzono natomiast dla studentów patrologii, w wymiarze dwóch godzin tygodniowo przez cztery semestry. Miały one na celu zapoznanie się ze źródłowymi tekstami z zakresu historii i wyrobienie umiejętności ich analizy. Przedmiotem ćwiczeń były przede wszystkim historie kościelne począwszy od Euzebiusza z Cezarei, a dalej Sokratesa Scholastyka, Hermiasza Sozomena i Ewagriusza Scholastyka, a także poznanie i analizę innych wybranych tekstów źródłowych. Jako kryterium zaliczenia ćwiczeń przyjęto znajomość treści powyższych tekstów źródłowych oraz opracowanie referatów na określone tematy, których podstawę opracowania stanowiły powyższe źródła. W czasie funkcjonowania studiów historii Kościoła i patrologii w ramach Wydziału Teologicznego, ćwiczenia te prowadził również ks. Wincenty Myszor.

Po przejściu w 1987 r. historii Kościoła wraz z innymi specjalnościami kierunku historycznego na Wydział Kościelnych Nauk Historycznych i Społecznych w ramach zajęć dydaktycznych nadal kontynuowano wykład kursoryczny z historii Kościoła starożytnego w liczbie dwóch godzin przez 4 semestry, dla studentów historii Kościoła, historii literatury wczesnochrześcijańskiej i archeologii chrześcijańskiej. W latach 1987-1997 prowadzili je kolejno ks. prof. dr hab. Wincenty Myszor, ks. dr hab. Jan Gliściński i ks. dr Tadeusz Kołosowski. W 1997 r. zważywszy na pojawiającą się w Polsce większą liczbę opracowań syntetycznych i podręczników historii uznano za właściwe zrezygnowanie z wykładów kursorycznych na rzecz większej ilości wykładów monograficznych. Stąd od 1997 r. studenci historii Kościoła na wszystkich latach studiów mają możliwość każdego roku wysłuchania jednego z dwu wykładów monograficznych z historii starożytnej. Obecnie materiał podawany dotychczas

\footnotetext{
12 Por. tamże.
} 
w formie wykładu kursorycznego połączono z ćwiczeniami. Wykład kursoryczny z historii Kościoła starożytnego prowadzony jest nadal (ks. dr Tadeusz Kołosowski) dla studentów archeologii chrześcijańskiej. Pracownicy Katedry Historii Kościoła Starożytnego podjęli się ponadto prowadzenia wykładu kursorycznego z historii Kościoła starożytnego po powstaniu w 1996 roku Zaocznego Studium Nauk Historycznych. W roku akademickim 1996/97 wykład ten prowadził ks. prof. dr hab. Wincenty Myszor, a w latach 1997-1999 ks. dr Tadeusz Kołosowski.

Ćwiczenia z historii starożytnej Kościoła podczas pierwszych lat funkcjonowania nowego wydziału nadal były prowadzone wyłącznie dla studentów patrologii. Prowadzili je kolejno ks. Jan Gliściński i ks. Tadeusz Kołosowski. Ćwiczenia te także dla studentów historii Kościoła wprowadzono w 1995 r., najpierw w liczbie dwóch godzin tygodniowo przez 2 semestry, a od 1997 r. przez 4 semestry. Prowadził je Tadeusz Kołosowski.

Od momentu powstania Wydziału Kościelnych Nauk Historycznych i Społecznych pracownicy Katedry prowadzą także wykłady monograficzne. W ostatnich latach ks. prof. dr hab. Wincenty Myszor przeprowadził wykłady monograficzne na następujące tematy: Duchowość monastyczna na Wschodzie w starożytności, Gnostycyzm i manicheizm, Chrześcijaństwo wśród religii Cesarstwa Rzymskiego. Ks. dr hab. Jan Gliściński zaś w czasie pracy w ATK i kierowania Katedrą Historii Kościoła Starożytnego w formie wykładu monograficznego przedstawił tematy: Polityka kościelna św. Hilarego z Poitiers, Dzieje sporów ariańskich, Sobory w starożytności. Tematami dotychczasowych wykładów monograficznych ks. dra Tadeusza Kołosowskiego były: Duszpasterstwo wsi u schylku starożytności, Historiografia starożytna, Sobory w starożytności, Donatyzm, Stosunki państwo-Kościót w starożytności chrześcijańskiej.

Od kilku lat prowadzone jest z historii starożytnej Kościoła seminarium naukowe (magisterskie i doktorskie). Prowadzili je: ks. dr hab. Jan Gliściński, ks. dr Tadeusz Kołosowski (czasowo seminarium magisterskie), a obecnie ks. prof. dr hab. Wincenty Myszor. Dotychczas powstały: 1 praca magisterska pod kierunkiem ks. Jana Gliścińskiego, 1 praca magisterska pod kierunkiem ks. Tadeusza Kołosowskiego oraz 1 rozprawa doktorska pod kierunkiem ks. prof. Wincentego Myszora. Obecnie pod kierunkiem ks. prof. Wincentego Myszora przygotowywane są 2 rozprawy doktorskie (otwarte przewody) i 5 prac magisterskich. W seminarium uczestniczy ponadto kilku studentów, którzy prace dyplomowe piszą w ramach innego seminarium.

3. Kierunki badań naukowych i publikacje. O działalności naukowo-badawczej Katedry Historii Kościoła Starożytnego stanowią kierunki badań naukowych i publikacje pracowników. Główne kierunki badań naukowych wszystkich pracowników związanych z Katedrą (ks. Myszor, ks. Gliściński, ks. Koło- 
sowski) dotyczą zagadnienia herezji i schizm w Kościele starożytnym, polemiki Ojców Kościoła, zagadnień społeczno-gospodarczych, działalności misyjnej i chrystianizacyjnej Kościoła, ze szczególnym uwzględnieniem okresu wędrówek ludów oraz problemów stosunków pomiędzy Kościołem a Cesarstwem Rzymskim. Badania te w dużej mierze obejmują zarówno historię starożytną Kościoła, jak i patrologię. Wynika to w jakiś sposób z faktu, że wszyscy pracownicy katedry byli, bądź są patrologami. Stanowi to także o ścisłej wzajemnej współpracy naukowo-badawczej jak i dydaktycznej pracowników Katedry Historii Kościoła Starożytnego z pracownikami katedr działających w ramach historii literatury wczesnochrześcijańskiej.

Główne kierunki badań naukowych obecnego kierownika katedry ks. prof. dr hab. Wincentego Myszora dotyczą antycznego gnostycyzmu, koptyjskiej biblioteki z Nag Hammadi (odkrytych w 1945 r. w Egipcie oryginalnych tekstów przede wszystkim gnostyckich). Współpracuje on od 1975 r. z Patristische Kommission der Akademie der Wissenschaften w Bonn (w zakresie informacji naukowej) oraz z Zakładem Egiptologii Instytutu Orientalistycznego Uniwersytetu Warszawskiego (w zakresie studiów języka koptyjskiego). Innym kierunkiem jego badań o charakterze historycznym są zagadnienia gospodarczospołeczne Kościoła w starożytności, zwłaszcza w pierwszych trzech wiekach, jak np. zagadnienie pracy, działalności charytatywnej, służby wojskowej, itd. Punktem jego zainteresowań badawczych jest także działalność misyjna w Kościele starożytnym, szczególnie idea misyjna Kościoła. Owocem badań naukowych jest ponad 100 prac samoistnych i artykułów, które prezentują wyniki tych badań.

Prace badawczo-naukowe ks. dr hab. Jana Gliścińskiego (zm. 27 VII 1998) dotyczyły przede wszystkim historii arianizmu, arianizmu jako religii narodowej plemion germańskich, polityki kościelnej przedstawicieli ówczesnego episkopatu oraz problematyki społecznej i pedagogicznej w nauczaniu Ojców Kościoła. Opublikował 3 książki oraz ponad 60 artykułów i recenzji książek naukowych.

Ks. dr Tadeusz Kołosowski w pracy naukowo-badawczej zajmuje się działalnością chrystianizacyjną Kościoła, przede wszystkim w okresie wędrówekludów, historią polityczną i społeczną, w sposób szczególny relacjami pomiędzy Kościołem a Cesarstwem Rzymskim i nauką o państwie u pisarzy wczesnochrześcijańskich, dziejami chrześcijaństwa w Afryce Rzymskiej, w sposób szczególny kwestią koegzystencji pomiędzy wyznawcami Kościoła katolickiego a donatystami po wybuchu schizmy donatystycznej. Wyniki badań publikowane są w artykułach naukowych; opublikował ponad 15 artykułów i kilka recenzji książek naukowych. 


\section{DER LEHRSTUHL DER GESCHICHTE DER ANTIKEN KIRCHE \\ IN DER AKADEMIE DER KATHOLISCHEN THEOLOGIE IN WARSCHAU}

(Zusammenfassung)

Der Artikel beschreibt Entstehung und Entwicklung des Lehrstuhles der Geschichte der antiken Kirche in der Akademie der Katholischen Theologie in Warschau, Personbestand, didaktische Beschäftigung der Professoren, Adjunkten und Assistenten, Richtungen der wissenschaftlichen Forschungen und hauptsächliche Bekanntmachungen. 